\title{
Pink Wax Scale (Ceroplastes rubens) a Growing Threat to Agriculture in Sri Lanka
}

\author{
K.V.A.I.K. Vithana* ${ }^{*}$ U.G.A.I. Sirisena ${ }^{1}$ and K.S.Hemachandra ${ }^{2}$
}

Horticultural Crops Research and Development Institute, Gannoruwa, Sri Lanka

\begin{abstract}
Wax scale (Hemiptera: Sternorrhyncha: Coccidae), has become an increasingly concerning pest on crop plants and perennials in Sri Lanka. Recent field reports indicate outbreaks of wax scales population and rapid spread on a large number of economically important plants. A methodical study of this species has not been conducted and the identity of the species has not been confirmed yet. A field survey was conducted in three districts: Gampaha, Kalutara and Kandy, from July 2017 to August 2018, to identify the wax scale species causing the recent outbreaks and to record its distribution and host range. The wax scale species was identified as Ceroplastes rubens Maskell (pink wax scale) and infestation level of each host plant was presented. The species was prevalent on hostplants belonging to 28 families in all three districts surveyed, among the host-plants families, Araceae (16.9\%), Anacardiaceae (16.1\%), Myrtaceae (12.7\%) and Rubiaceae (10.2\%) found to be dominant. It was also found that the significantly higher $(p<0.05)$ infestation level in Gampaha district in compared to Kalutara and Kandy districts. The necessary actions need to be taken to control pink wax scale to prevent further spreading into other areas of the country.
\end{abstract}

Keywords: Host-plant, pest, Sri Lanka, wax scale

\section{INTRODUCTION}

Scale insects refer to a group of sap-sucking insects, classified under the Hemipteran Suborder: Sternorrhyncha, Infraorder: Coccomorpha and Family: Coccidae. Among them, wax scales, of the genus Ceroplastes are an economically important phytophagous insect group. Adult females and nymphs of wax scales cause direct damage through feeding on plant phloem sap. They excrete sugary honeydew, which fouls plant surfaces and provides a medium for the growth of sooty mold fungus on leaves, so reducing the active photosynthetic area (Argov et al., 1987). Heavy infestations of wax scales can cause leaf discoloration and premature drop, branch dieback and even plant death. Sooty mold fouling can lead to a significant reduction in photosynthesis, reducing yield. The scales therefore cause loss of production and reduce the aesthetic value of the crop or the produce (Hodges et al., 2000). In addition, some species of wax scale are virus disease vectors, for example $C$. rusci is known to carry plant viruses (La Notte et al., 1997).

Currently, 144 species and six subspecies of wax scales have been reported worldwide (García Morales et al., 2016). The first and most comprehensive record of the presence of the

\footnotetext{
${ }^{1}$ Faculty of Agriculture, Rajarata University of Sri Lanka, Sri Lanka

${ }^{2}$ Faculty of Agriculture, University of Peradeniya, Sri Lanka

* Corresponding author: anuvithana2014@gmail.com
} 
family Coccidae in Sri Lanka was done during the British era, when 71 species in 28 genera were recorded by Green (1937). At present, seven species of subfamily Ceroplastinae, such as Ceroplastes actiniformis Green, Ceroplastes ceriferus (Fabricius), Ceroplastes floridensis (Comstock), Ceroplastes pseudoceriferus Green, Ceroplastes rubens Maskell, Ceroplastes sinensis Del Guercio and Ceroplastes stellifer Westwood belonging to ceroplatinae have been recorded in Sri Lanka (Green, 1935; Sirisena, et al., 2016; García Morales et al., 2016). Although these wax scales are spreading at an alarming rate, so far, a methodical study on this scale has not been conducted and the identity of the species has not been confirmed. The present study therefore was conducted to identify the wax scale species causing the recent outbreak and record its distribution and host range.

\section{METHODOLOGY}

A field survey was conducted to study the occurrence of a wax scale species. Eleven sites located in three administrative districts, Gampaha, Kalutara and Kandy were surveyed during July 2017 to August 2018. The survey was supported by the extension officers in the districts concerned. The awareness of provincial agricultural extension officers regarding the wax scale threat to horticultural crops was raised in advance. Extension officers were requested to report the presence of the pest on horticultural and non-horticultural crops in their areas of jurisdiction. From the locations reported by the field officers, 3 to 4 in each of the 3 districts were selected randomly for field sampling.

The most severely affected tree/bush identified at each location was georeferenced using a GPS receiver and which was considered as the center point of a transect of having a length of $200 \mathrm{~m}$. Along the transect, all the vegetation, including trees, shrubs and weed species that might carry infestations were examined. Wax scale-infested host-plant samples were collected from vegetation on the transect line. The sampling method varied according to the size of the host plant/tree. In the case of trees, twenty infested leaves per tree and four infested shoots (30 cm in length and 1.0-1.2 $\mathrm{mm}$ in diameter) (Hendawy et. al., 2013) found nearest to the perimeter of the canopy were sampled. Each tree was sampled from the four cardinal directions (North, East, South and West) as five leaves and one branch per direction, using a sharp knife (Hendawy et. al., 2013). In the case of shrubs, five to ten leaves or three $30 \mathrm{~cm}$ lengths of infested twigs were sampled. In the case of small plants/weeds, the whole plant was sampled. Each sampled twig/plant was placed in a labeled, mesh fitted plastic jar or paper bag containing a sample number, the locality, date of collection and notes on the host plant and its habitat. Data were recorded on the abundance of wax scale insects per unit area (number of scales $/ \mathrm{cm}^{2}$ ); and the number of live, individual insect life stages (nymphs and adult females) on the leaves. Paper bags containing the specimens were transferred carefully to the Entomology Laboratory at the Horticultural Crops Research and Development Institute, Gannoruwa for further study. Plants and plant parts suspected to be infested by the wax scales were closely examined in the laboratory. The host-plant specimens were identified up to the species level with the collaboration of a Botanist/Taxonomist. Photographs of fresh specimens were taken for the confirmation of the identity. The live appearance of the wax scale insects were recorded using digital photography. The scale insect specimens were prepared for compound light microscopy using the slide-mounting method described by Sirisena et al. (2013). Photographs were taken using a high-powered microscopic camera (OPTIKA B5). Slide-mounted adult female specimens were identified under a compound light microscope (Motic BA 300) with objectives between 10 x 20 and 10 $\mathrm{x} 40$, using the keys and illustrations in Green (1896; 1908); Sankaran (1962); Williams and Watson (1990); and Hodgson and Peronti (2012). The abundance and infestation levels were 
compared using ANOVA procedure in SAS statistical software and the descriptive statistics were calculated using Microsoft excel program. Voucher specimens were deposited in the insect collection of Horticultural Crops Research and Development Institute (HORDI), Gannoruwa, Peradeniya.

\section{RESULTS AND DISCUSSION}

The wax scale spreading an epidemic level in the surveyed areas was identified as Ceroplastes rubens Maskell; this identification was confirmed digitally by the Insects Division, Department of Life Sciences, The Natural History Museum, London, U.K. The species was first recorded from Sri Lanka by Green (1896). Two colour forms of C. rubens, pink and white were collected. However the white colour form was dominant (Figure 1). Malumphy (2014) also recorded white-waxed individuals of $C$. rubens in Sri Lanka. Some other Ceroplastes species like $C$. rusci have also been recorded with white and pink colour forms, which might be induced by different environmental conditions.
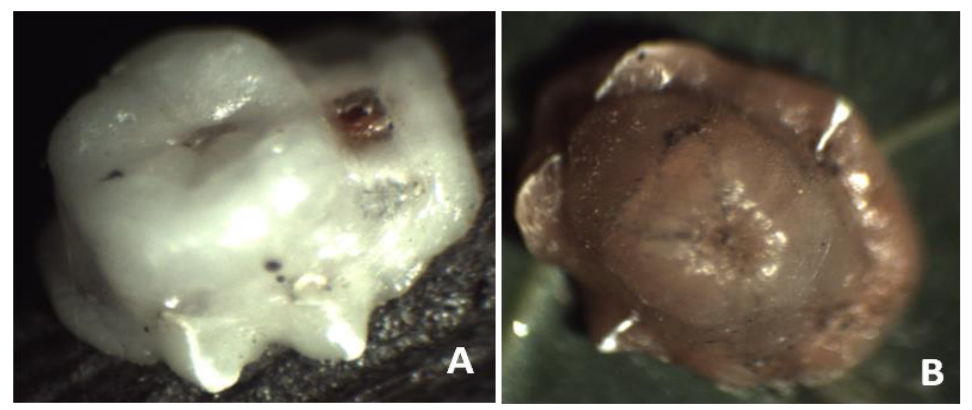

Figure 1. Adult female of Ceroplastes rubens A) White colour type B) pink colour type

\section{Live appearance of $C$. rubens}

Adult female $C$. rubens are globular and coated with a thick layer of wet pinkish or whitish wax (Figure 1). In dorsal view, they appear sub-rectangular or oval; they may grow to over $3.1 \mathrm{~mm}$ in diameter. Adult males are much smaller and have one pair of wings. The pink eggs are laid under the adult female's body, protected by the waxy test. The first-instar crawlers are pink and have functional legs. The second- and third-instar nymphs secrete clumps of wax over themselves, giving them a star-like appearance.

\section{Diagnostic characteristics of slide-mounted specimens}

Slide-mounted adult female was broadly oval, anal process was short, heavily sclerotized, stigmatic clefts distinct, each containing about 25-30 stigmatic setae of which three were large and prominent with blunted tips (Figure 2). Antennae were each six segmented and legs were small and poorly developed. Eight area was present in the dorsum, without pores, ducts or setae. Tubular ducts were cylindrical, fine, fairly numerous on cuticle between clear areas. The dorsal setae were few, short and truncate. Marginal setae were short, stiff, acute and slightly curved, sparse. Venter was an inter-antennal setae usually numbering two pairs or absent. Multilocular pores were present around vulva. Spiracular disc pores were present in broad band between each spiracle and corresponding spiracular cleft. Tubular ducts were absent from venter. 

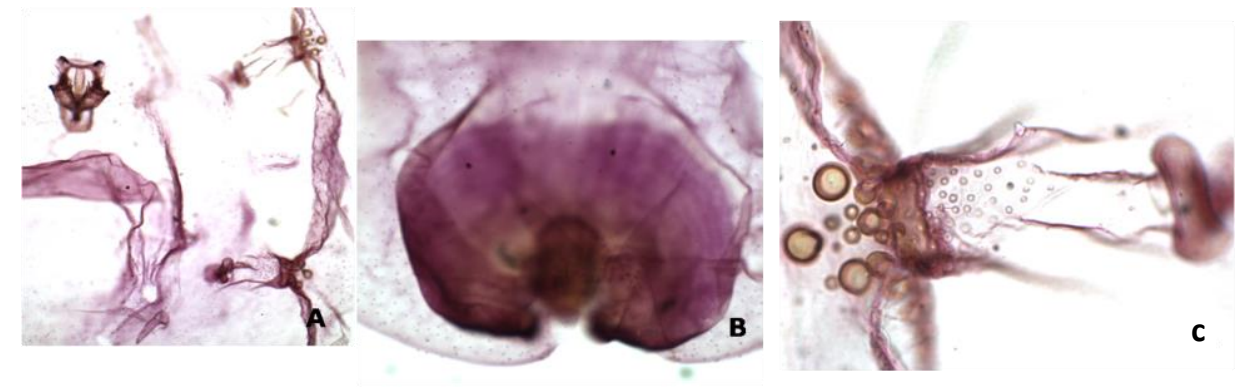

Figure 2. Slide mounted specimens of Ceroplastes rubens A) mouth parts and spiracle B) anal plate $C$ ) stigmatic furrow and setae

The occurrence (\%) of C. rubens in different plant families and species

This species was prevalent on hosts belonging to 28 families of plants. However, there was a variation in distribution of species among the districts. It was noted that the scale species has a pronounced preference for Aglaonema spp. in Gampaha district (Table 1), Ixora spp. and Mangifera indica in Kaluthara district (Table 2) and Mangifera indica and Syzygium varieties in Kandy district (Table 3).

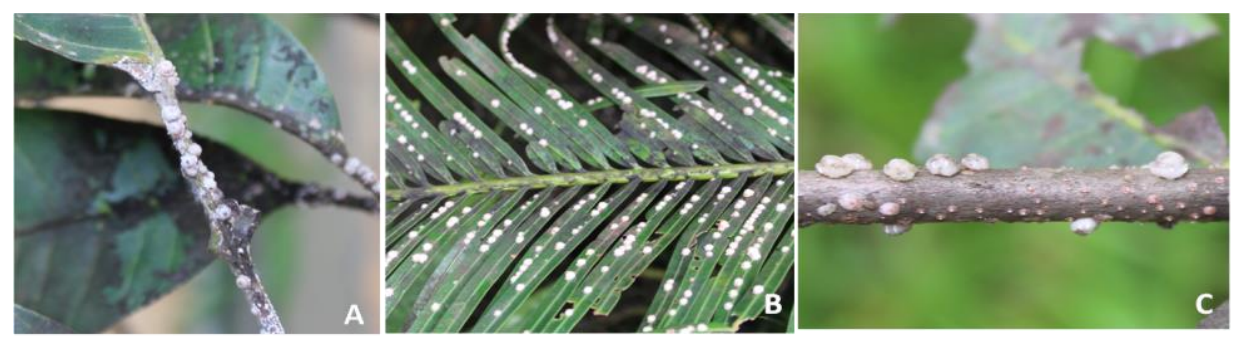

Figure 3. Ceroplastes rubens on A) Mango B) Cycas C) Ixora 
Table 1. The distribution and host range of Ceroplastes rubens in Gampaha District

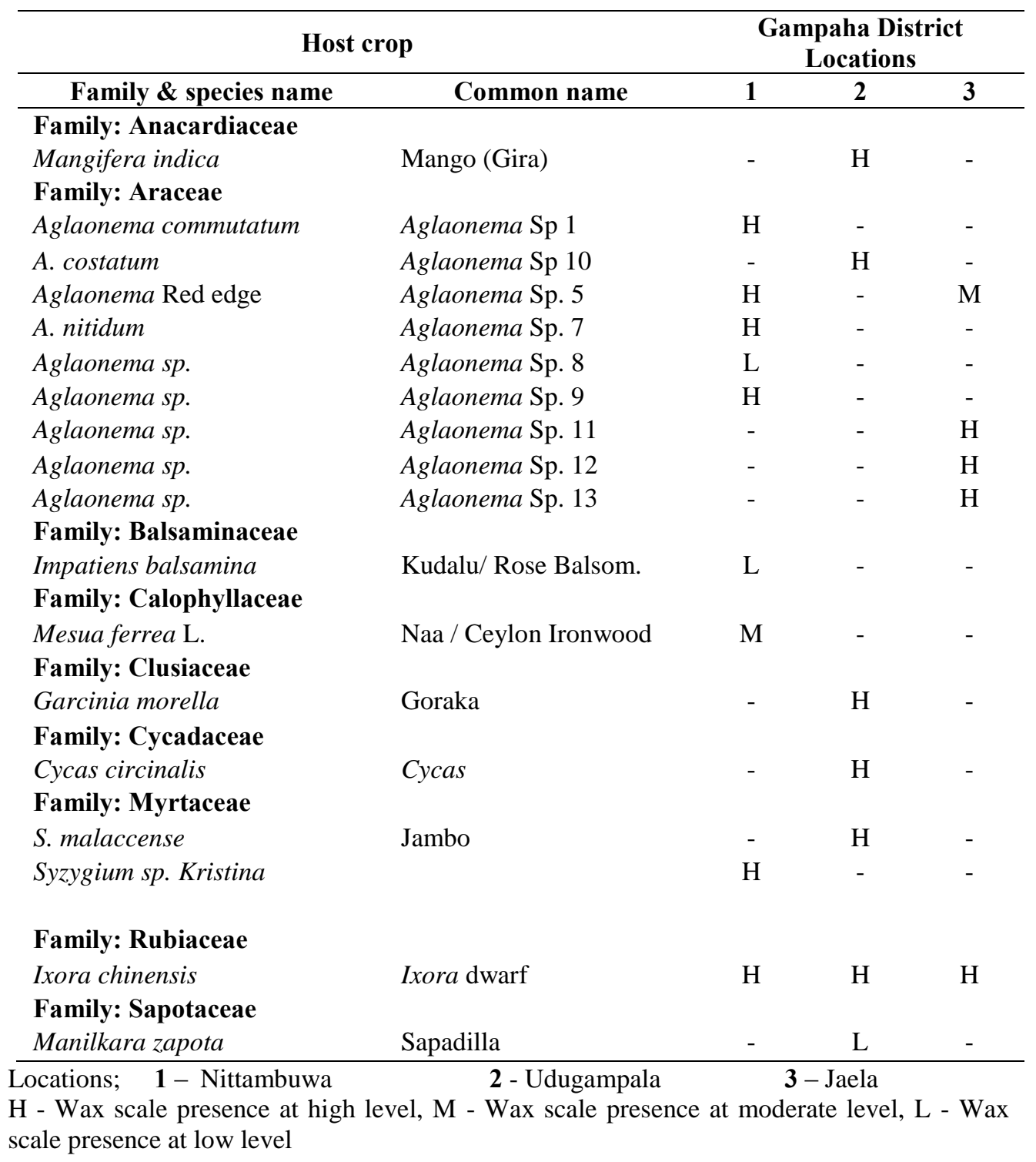


Table 2. The distribution and host range of Ceroplastes rubens in Kalutara District

\begin{tabular}{|c|c|c|c|c|c|}
\hline \multicolumn{2}{|c|}{ Host crop } & \multicolumn{4}{|c|}{$\begin{array}{c}\begin{array}{c}\text { Kalutara District } \\
\text { Locations }\end{array} \\
\end{array}$} \\
\hline Family \& species name & Common name & 1 & 2 & 3 & 4 \\
\hline $\begin{array}{l}\text { Family: Amaranthaceae } \\
\text { Alternanthera dentata } \\
\text { Family: Anacardiaceae }\end{array}$ & Red Mukunuwenna & - & - & M & - \\
\hline Mangifera indica & $\begin{array}{l}\text { Mango (Rata) } \\
\text { Mango (Tom EJC) }\end{array}$ & $\begin{array}{l}\mathrm{H} \\
-\end{array}$ & $\begin{array}{l}- \\
\mathrm{H}\end{array}$ & $\begin{array}{l}\mathrm{H} \\
-\end{array}$ & $\begin{array}{l}\mathrm{H} \\
-\end{array}$ \\
\hline $\begin{array}{l}\text { Spondius dulcis } \\
\text { Family: Apocynaceae }\end{array}$ & Ambarella dwarf & - & - & $\mathrm{H}$ & - \\
\hline $\begin{array}{l}\text { Carissa grandiflorum } \\
\text { Family: Araceae }\end{array}$ & Damson & - & - & $\mathrm{H}$ & - \\
\hline A. marantifolium & Aglaonema Sp. 2 & - & - & $\mathrm{H}$ & - \\
\hline Aglaonema Red edge & Aglaonema Sp. 5 & - & - & - & $\mathrm{H}$ \\
\hline $\begin{array}{l}\text { Aglaonema sp. Pink veined } \\
\text { Family: Asteraceae }\end{array}$ & Aglaonema Sp. 6 & - & $\mathrm{H}$ & - & $\mathrm{L}$ \\
\hline $\begin{array}{l}\text { Melampodium paludosum } \\
\text { Family: Balsaminaceae }\end{array}$ & & - & - & $\mathrm{H}$ & - \\
\hline $\begin{array}{l}\text { Impatiens balsamina } \\
\text { Family: Clusiaceae }\end{array}$ & Kudalu/ Rose Balsom. & - & - & $\mathrm{H}$ & - \\
\hline $\begin{array}{l}\text { G. mangustana } \\
\text { Family: Cycadaceae }\end{array}$ & Mangustin & M & - & - & - \\
\hline Cycas circinalis & Cycas & - & - & $\mathrm{H}$ & - \\
\hline $\begin{array}{l}\text { C. revoluta } \\
\text { Family: Hydrangeaceae }\end{array}$ & Cycas & $\mathrm{H}$ & $\mathrm{H}$ & - & $\mathrm{H}$ \\
\hline $\begin{array}{l}\text { Hydrangea sp. (paniculata) } \\
\text { Family: Lauraceae }\end{array}$ & Hydrangea & - & - & $\mathrm{L}$ & - \\
\hline $\begin{array}{l}\text { Cinnamomum verum } \\
\text { Family: Myrtaceae }\end{array}$ & Cinnamon & - & - & M & - \\
\hline Syzygium samarangense & Small jambu & - & $\mathrm{H}$ & - & $\mathrm{H}$ \\
\hline $\begin{array}{l}\text { Syzygium sp. Kristina } \\
\text { Family: Pinaceae }\end{array}$ & & $\mathrm{H}$ & - & - & - \\
\hline $\begin{array}{l}\text { Cedrus deodara } \\
\text { Family: Polypodiaceae }\end{array}$ & Devadara & - & M & - & - \\
\hline $\begin{array}{l}\text { Asplenium nidus } \\
\text { Family: Rubiaceae }\end{array}$ & Birds' Nest Fern & - & - & $\mathrm{H}$ & $\mathrm{L}$ \\
\hline Ixora chinensis & Ixora dwarf & - & $\mathrm{H}$ & $\mathrm{H}$ & - \\
\hline I. coccinea & Ixora & - & $\mathrm{H}$ & $\mathrm{H}$ & - \\
\hline $\begin{array}{l}\text { I. lutea } \\
\text { Family: Rutaceae }\end{array}$ & Ixora & - & $\mathrm{H}$ & $\mathrm{H}$ & - \\
\hline $\begin{array}{l}\text { C. sinensis } \\
\text { Family: Santalaceae }\end{array}$ & Orange & - & - & $\mathrm{L}$ & - \\
\hline $\begin{array}{l}\text { Santalum album } \\
\text { Family: Sapotaceae }\end{array}$ & Sandalwood & - & - & M & - \\
\hline $\begin{array}{l}\text { Manilkara zapota } \\
\text { Family: Solanaceae }\end{array}$ & Sapadilla & - & - & $\mathrm{H}$ & $\mathrm{H}$ \\
\hline Solanum macrocarpon & Brinjal & - & - & $\mathrm{H}$ & - \\
\hline
\end{tabular}


H - Wax scale presence at high level, M - Wax scale presence at moderate level, L - Wax scale presence at low level

Table 3. The distribution and host range of Ceroplastes rubens in Kandy District, in the survey during July 2017- August 2018

\begin{tabular}{|c|c|c|c|c|c|}
\hline \multicolumn{2}{|c|}{ Host crop } & \multicolumn{4}{|c|}{$\begin{array}{l}\text { Kandy District } \\
\text { Locations }\end{array}$} \\
\hline Family \& species name & Common name & 1 & 2 & 3 & 4 \\
\hline \multicolumn{6}{|l|}{ Family: Acanthaceae- } \\
\hline Ruellia tuberosa & & - & - & $\mathrm{H}$ & \\
\hline \multicolumn{6}{|l|}{ Family: Anacardiaceae } \\
\hline Mangifera indica & Mango (Amarapali) & $\mathrm{H}$ & - & - & - \\
\hline & Mango (Dampara) & $\mathrm{H}$ & - & - & - \\
\hline & Mango (Tom EJC) & $\mathrm{H}$ & - & - & - \\
\hline & Mango (Malwana) & $\mathrm{H}$ & - & - & - \\
\hline & Mango (Karabawa) & $\mathrm{H}$ & - & - & - \\
\hline & Mango (Velleikolomban) & - & - & $\mathrm{H}$ & - \\
\hline & Mango (Karthakolomban) & - & - & $\mathrm{H}$ & - \\
\hline $\begin{array}{l}\text { Spondius dulcis } \\
\text { Family: Araceae }\end{array}$ & Ambarella dwarf & $\mathrm{H}$ & - & - & - \\
\hline Aglaonema commutatum & Aglaonema Sp 1 & - & $\mathrm{H}$ & - & - \\
\hline $\begin{array}{l}\text { A. commutatum var. } \\
\text { pseudobractaeatum }\end{array}$ & Aglaonema sp 3 & - & $\mathrm{H}$ & - & - \\
\hline A. marantifolium & Aglaonema Sp. 2 & - & $\mathrm{H}$ & - & - \\
\hline Aglaonema Red edge & Aglaonema Sp. 5 & - & - & $\mathrm{H}$ & - \\
\hline \multicolumn{6}{|l|}{ Family: Araliaceae } \\
\hline Schefflera arboricola & Schefflera varigated araliya & - & M & - & - \\
\hline $\begin{array}{l}\text { Polyscias guilfoylei victoriae } \\
\text { Family: Celastraceae }\end{array}$ & Dwarf Koppa kola & - & $\mathrm{H}$ & - & - \\
\hline $\begin{array}{l}\text { Salacia chinensis } \\
\text { Family: Clusiaceae }\end{array}$ & Himbutu & $\mathrm{H}$ & - & - & - \\
\hline $\begin{array}{l}\text { Garcinia morella } \\
\text { Family: Cycadaceae }\end{array}$ & Goraka & - & - & - & $\mathrm{H}$ \\
\hline Cycas circinalis & Cycas & $\mathrm{H}$ & - & - & - \\
\hline $\begin{array}{l}\text { C. media } \\
\text { Family: Ebenaceae }\end{array}$ & Cycas & - & $\mathrm{H}$ & - & - \\
\hline $\begin{array}{l}\text { Diospyros kaki } \\
\text { Family: Euphorbiaceae }\end{array}$ & Persimmon & $\mathrm{H}$ & - & - & - \\
\hline $\begin{array}{l}\text { Antidesma bunius L. Spreng } \\
\text { Family: Gesneriaceae }\end{array}$ & Karawalakabella /Bignay & $\mathrm{H}$ & - & - & - \\
\hline $\begin{array}{l}\text { Saintpaulia ionantha } \\
\text { Family: Iridaceae }\end{array}$ & African violet & - & $\mathrm{L}$ & - & - \\
\hline $\begin{array}{l}\text { Iris domestica } \\
\text { Family: Lauraceae }\end{array}$ & Leopard lily & - & - & - & $\mathrm{L}$ \\
\hline $\begin{array}{l}\text { Persea americana } \\
\text { Family: Malvaceae }\end{array}$ & Avocado & - & - & - & $\mathrm{L}$ \\
\hline Hibiscus mutabilis & Bengali rose & - & - & - & $\mathrm{M}$ \\
\hline
\end{tabular}




\author{
Family: Myrtaceae \\ Nephelium lappaceum \\ S. campanulata \\ S. cumini \\ S. cumini \\ S. malsciensis \\ S. samarangense \\ S. samarangense \\ S. samarangense
}

Family: Oleandraceae

Nephrolepis excltatae

Family: Polypodiaceae

Asplenium nidus

Family: Rubiaceae

I. coccinea

I. hybrida

I. hybrids

I. lutea

Family: Rutaceae

Citrus maxima

C. sinensis

Family: Sapotaceae

Chrysophyllum caniote
Rambutan

Kristina

Madan

Madan (Black plum)

Pini Jambu

Small jambu

Green Jambu

Rose Giant

Fern

Birds' Nest Fern

Ixora

Ixora

Ixora

Ixora

Pumello (Surath)

Orange
$\begin{array}{llll}\mathrm{H} & - & - & - \\ - & - & \mathrm{H} & - \\ \mathrm{H} & - & - & - \\ \mathrm{H} & - & - & - \\ \mathrm{H} & - & - & - \\ \mathrm{H} & - & - & \mathrm{H} \\ \mathrm{H} & - & - & - \\ \mathrm{H} & - & - & - \\ & & & \\ - & \mathrm{M} & - & -\end{array}$

- L - -

- $\quad$ - $\quad-\quad \mathrm{H}$

- - L -

- H - -

- L H -

M

$-\quad \mathrm{L}$

\begin{tabular}{lll}
\hline Locations; & $\mathbf{1}$ - Fruit Plant Nursery, Gannoruwa & $\mathbf{2}$ - Gannoruwa \\
& $\mathbf{3}$ - Kahapathwala & $\mathbf{4}$ - Danthure
\end{tabular}

H - Wax scale presence at high level, M - Wax scale presence at moderate level, L - Wax scale presence at low level

The highest relative percentage of occurring was recorded in family Araceae (16.9\%), followed by Anacardiaceae (16.1\%), Myrtaceae (12.7\%), Rubiaceae (10.2\%) and in other families it was below $10 \%$. The mean infestation was significantly higher $(P<0.05)$ in family Araceae $\left(9.74 \pm 2.6\right.$ insects $\left./ 10 \mathrm{~cm}^{2}\right)$ and Myrtaceae $\left(9.29 \pm 1.5\right.$ insects $\left./ 10 \mathrm{~cm}^{2}\right)$ in compared to other families and the lowest mean infestations $\left(0.02 \pm 0.52\right.$ insects $\left./ 10 \mathrm{~cm}^{2}\right)$ was recorded in family Gesneriaceae

\section{The distribution and the mean infestation of $C$. rubens in different ocations}

The mean infestation of $C$. rubens was significantly $(P<0.05)$ high in the Gampaha district $\left(9.8 \pm 2.7\right.$ insects $\left./ 10 \mathrm{~cm}^{2}\right)$ in compared to the Kalutara $\left(5.8 \pm 1.1\right.$ insects $\left./ 10 \mathrm{~cm}^{2}\right)$ and Kandy $\left(4.2 \pm 0.5\right.$ insects $\left./ 10 \mathrm{~cm}^{2}\right)$ districts.

\section{CONCLUSIONS}

The wax scale species which is responsible for the recent outbreaks of wax scale insect on crops and perennial plants in Sri Lanka has been identified as Ceroplates rubens Maskell. In Sri Lanka, there appear to be two distinct forms of this species based on the wax colour (either pink or white wax). Among the host plants, mango, Garcinia, Syzygium and Ixora were found to be the plant species most susceptible to attack by the scale. 


\section{ACKNOWLEDGEMENT}

The Director, PGIA is thanks for providing funding to carry out this research through the Research Facilitation Fund of the PGIA. We wish to thank Dr. P. Weerasinghe (Director, HORDI, Gannoruwa) for the administrative support given to conduct this study. We wish to acknowledge the Provincial Directors of Agriculture and extension officers in the Central and Western provinces who identified most of the pest locations for the survey. Mr. P.R.S.D. Bandaranaike (STO) is also acknowledged for his voluntary expert support in host plant identification. We wish to thank Mr. P. Nishantha (ADA), for facilitating the use of a microscopic camera.

\section{REFERENCES}

Argov, Y., Podoler, H., Bar-Shalom, O. and Rosen, D. (1987). Mass rearing of the Florida wax scale, Ceroplastes floridensis, for production of natural enemies. Phytoparasitica 15, 277-287.

García, M., Denno, B.D., Miller, D.R., Miller, G.L., Ben-Dov, Y. and Hardy, N.B. (2016). ScaleNet: a literature-based model of scale insect biology and systematics. Database at http://scalenet.info. doi: 10.1093/database/bav118.

Green, E.E. (1896). Catalogue of Coccidae collected in Ceylon. Indian Mus. Notes 4 (18961900), 2-10.

Green, E. E. (1937). An annotated list of the Coccidae of Ceylon, with emendations and additions to date. Ceylon J. Sci. 20, 277-341.

Green, E.E. (1935). On a species of Ceroplastes (Hemiptera: Coccidae), hitherto confused with C. ceriferus Anders. Stylops 4(8), 180.

Green, E.E. (1908). Remarks on Indian scale insects (Coccidae), Part III. With a catalogue of all species hitherto recorded from the Indian Continent. Mem. Dept. Agr. Ent. Ser. (India) 2, $15-46$.

Green, E.E. (1909). The Coccidae of Ceylon. Part IV. Dulau \& Co., London, U.K, pp. 268278.

Hendawy, A.S., Saad, I.A.I. and Rehab, H.T. (2013). Survey of Scale Insects, Mealy bugs and Associated Natural Enemies on Mulberry Trees in the Nile Delta. Egypt J. Agric. Res. 91(4), 1447-1458.

Hodgson, C.J. and Peronti, A.L.B.G. (2012). A revision of the wax scale insects (Hemiptera: Sternorrhyncha: Coccoidea: Ceroplastinae) of the Afrotropical Region. Zootaxa 3372, 1-265.

Hodges, G.S., Ruter J.R. and Braman S.K. (2000). Susceptibility of Ilex species, hybrids and cultivars to Florida wax scale. J. Environ. Horticulture. 19: 32-36. 
La Notte P., Buzkan N., Choueiri E., Minafra A., and Martelli G.P. (1997). Acquisition and transmission of grapevine virus A by the mealybug Pseudococcus longispinus. J. Plant Pathol. 78, 79-85.

Malumphy, C. (2014). Pink wax scale, Ceroplastes rubens. The Food and Environment Research Agency, Sand Hutton, York, YO 41 1LZ, UK.

Sankaran, T. (1962). The external characters of the post-larval stages of the wax scale, Ceroplastes pseudoceriferus Green (Hemiptera: Coccidae). Indian J. Entomol. 24, 1-18.

Sirisena, U.G.A.I, Watson, G.W., Hemachandra, K.S., and Wijayagunasekara, H.N.P. (2013). A Modified Technique for the Preparation of Specimens of Sternorrhyncha for Taxonomic Studies. Trop. Agric. Res. 24(2), 139-149.

Sirisena, U.G.A.I., Watson, G.W., Hemachandra, K.S. and Wijayagunasekara, H.N.P. (2016). Diversity of soft scale insects (Hemiptera, Sternorrhyncha, Coccoidea) in Sri Lanka. Arthropod Diversity and Conservation in the Tropics and Sub-tropics, pp. 285-295.

Williams D.J. and Watson G.W. (1990). The scale insects of the tropical South Pacific region. Part 3: The soft scales (Coccidae) and other families. CAB International, Wallingford, U.K, pp. 267. 